\title{
God's Makwerekwere: Re-imagining the church in the context of migration and xenophobia
}

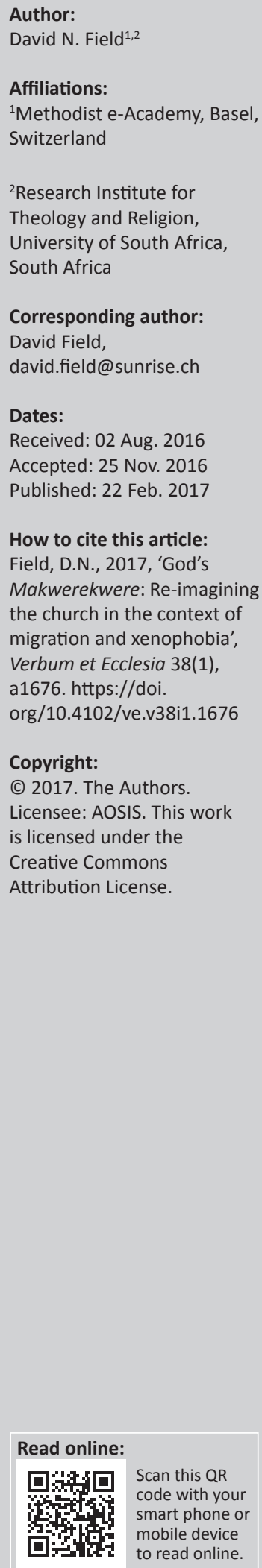

Mass migration and accompanying xenophobia are characteristics of the early 21st century and as such challenge the church to reimagine its identity. This article analyses migration and xenophobia particularly as they impact South Africa and then proposes the model of the church as God's Makwerekwere as an appropriate response. In doing so, it examines New Testament images of the church and argues that the church as God's Makwerekwere is a community in solidarity with the excluded, a community of affirmation of the excluded, a community of reconciliation and a transnational community.

Intradisciplinary and/or interdisciplinary implications: This article challenges the traditional discourse used in ecclesiology by proposing the image of the church as God's Makwerekwere. It roots this proposal in considerations from migration studies and New Testament studies. The aim is to re-imagining the church as a contribution to a transforming ecclesial praxis.

\section{Introduction}

Mass migration and accompanying xenophobia are characteristics of the early 21st century and as such challenge the church to reimagine its identity. This article analyses migration and xenophobia particularly as they impact South Africa and then proposes the model of the church as God's Makwerekwere as an appropriate response. In doing so, it examines New Testament images of the church and argues that the church as God's Makwerekwere is a community in solidarity with the excluded, a community of affirmation of the excluded, a community of reconciliation and a transnational community.

Mass migration is emerging as a determining feature of the first decades of the 21st century. The international news media has brought the plight of hundreds of thousands of people migrating to Europe to global attention. Yet, this is only a small part of the mass movement of people. Millions more are on the move fleeing wars, oppression, economic crises and environmental disasters. Their plight goes largely unnoticed as it occurs in poorer countries that the international media regards as having no significance. According to Oxfam, the countries presently hosting the most refugees are Jordan, Turkey, Palestine, Pakistan, Lebanon and South Africa. Together, these countries are hosting almost 12 million refugees (Oxfam 2016:3). The United Nations estimated that in $2015,13.9 \mathrm{~m}$ people were displaced because of war or persecution, bringing the total of displaced persons in the world to $65.3 \mathrm{~m}$ (UNHCR 2016). These figures do not include those who have migrated for other reasons. According to the United Nations in 2015, there were about $244 \mathrm{~m}$ people worldwide living outside of their home country (United Nations 2016).

Accurate figures are difficult to come by for South Africa, and different sources provide information that is not entirely compatible with the information from other sources. According to the 2011 census, there were about $2.2 \mathrm{~m}$ people living in South Africa who were born outside the country. This is $4.2 \%$ of the population. Of these, about $1.7 \mathrm{~m}$ had not acquired South African citizenship. ${ }^{1}$ These statistics probably do not include the majority of illegal migrants. Estimates of these vary from about $500000-1000000$ (Mwiti 2015). According to the Oxfam report of July 2016, South Africa is hosting 1217708 refugees (Oxfam 2016:3).

Migration and the presence of migrant populations provoke divergent responses from the indigenous population. In many situations, it has given rise to various forms of xenophobia. Vilified as Makwerekwere, migrants from other parts of Africa in South Africa regularly face hostility and hardship from both the general population and government officials. Violent attacks on foreigners in 2008 and 2015 in South Africa made international headlines. Sporadic incidents 1.For full statistics see Wilkinson (2015) and Lehohla (2012:36-44). 
of violence continue to occur. This is not unique to South Africa; attacks on migrants and acts of arson against asylum centres are frequent occurrences in other countries. Acts of public violence are, however, only one form of hostility towards foreigners; migrants are often confronted with diverse forms of structural and institutional hostility.

\section{Interpreting the signs of the time}

Pope Benedict XVI described migration as 'a sign of the times' (Benedictus 2005), that is, a feature of our contemporary times that challenges the church to reflection and a new praxis. As South African Christians have recently celebrated the 30th anniversary of the Kairos Document, it is appropriate to take this further and argue that the combination of migration and xenophobia is a kairos for the church - a time of challenge and opportunity that requires a response in praxis, ethics and theology.

As the Kairos Document argued, an adequate theological response must be grounded in social analysis. Failure to do this leads to cheap and superficial responses that contribute to obscuring the Kairos rather than adequately responding to it. In the first part of this article, I will briefly analyse key features of migration and xenophobia, with a particular focus on South Africa. The second part will deal with aspects of a theological response. The focus of this article is on the ecclesiological challenge. How does the presence of migrants in our contexts and the xenophobic response challenge us to rethink what it means to be the church? ${ }^{2}$

\section{Migration $^{3}$}

People migrate for many reasons, under diverse circumstances and for different lengths of time. They range from people trafficked to work in the sex industry to top executives transferred across the globe by transnational companies. Even within a given context, such as South Africa, there is considerable diversity both in terms of the reasons for immigration and the way in which the migrants are perceived by the local population. This article will focus on migrants from other African countries at the lower end of the economic spectrum - those who are contemptuously referred to as Makwerekwere. ${ }^{4}$

During the apartheid era, migrants from the rest of Africa were largely limited to people recruited to work in the mines who were returned to their own countries once they had completed their contracts. There was also limited illegal

2.Although there is significant literature dealing with ethical issues around migration and xenophobia, very little has been written on its significance for ecclesiology. Two significant exceptions are World Council of Churches (2015) and Snyder, Ralston and Brazal (2016)

3.For detailed studies of migration and xenophobia in South Africa, see Betts (2013:54-77), Heribert and Moodley (2015), Hassim, Kupe and Worby (2008), Klotz (2013), Landau (2011), Neocosmos (2010) and Nyamnjoh (2006).

4.The term Makwerekwere is a derogatory designation for people from othe countries in Africa. It is usually regarded as having an onomatopoeic reference to the un-understandable languages spoken by the foreigners or the manner in which they speak South African languages. It carries with it the stigma of being inferior, primitive, violent and criminal. It is a particular example of the use of language to primitive, violent and criminal. It is a particular example of the use of language to
exclude an 'Other' and hence a linguistic expression of xenophobia (see Nyamnjoh 2006:38-43) migration, particularly in border areas. The ending of apartheid led to new waves of migrants from other parts of Africa seeking to escape difficult conditions and to share in benefits of living in an economically advanced and politically stable context.

International law and most national laws distinguish between refugees and migrants; politicians often argue that these are completely different categories of people who should enjoy different rights and status. Under the UN Convention Relating to the Status of Refugees, countries are obligated to receive, protect and provide for refugees. A refugee is defined as someone who (UNHCR 2010):

... owing to a well-founded fear of being persecuted for reasons of race, religion, nationality, membership of a particular social group or political opinion, is outside the country of his nationality, and is unable to, or owing to such fear, is unwilling to avail himself of the protection of that country. (p. 14)

The Organisation of African Unity's Convention on Refugee Problems in Africa expanded this definition to include (OAU 1969):
... every person who, owing to external aggression, occupation, foreign domination or events seriously disturbing public order in either part or the whole of his country of origin or nationality, is compelled to leave his place of habitual residence in order to seek refuge in another place outside his country of origin or nationality. (p. 3)

In most cases, it is expected and sometimes enforced that refugees will return to their own countries if and when the circumstances change.

Other migrants are usually categorised as economic migrants, that is, people who decide to migrate in order to seek better economic conditions for themselves or their families. States have no obligations to provide for economic migrants, who are often subject to deportation if they have not acquired the relevant documentation. However, as Alexander Betts argues, the category of economic migrant covers a diverse group of people and contexts and is not an adequate analytical tool for responding to the contemporary context (Betts 2013:10-28). He argues that it needs to be supplemented by the category of survival refugees - these are people who leave their country of origin as a consequence of severe threat to their own or their family's survival. Such a threat could be political, economic, social or environmental. Such migrants, like refugees, engage on dangerous journeys to look for a new life; they are often abused, exploited and degraded on the way. Under international law, governments have no obligation to accept or protect such people. In most cases, they are treated as economic migrants and are required to follow the same route as others in obtaining residence and work permits.

Even if we accept the category of economic migrants for others who leave their countries to seek a better life themselves or their families, this needs further nuance. It can apply to the well-qualified person who is recruited by a 
major company and is paid a high salary, or the academic from an African university who takes up a position in a South African, European or North American university. It may be a person who has a job in his or her own country but can earn considerably more in South Africa or Europe and migrates in order to be able to support his or her family who remain. It can also apply to a person who has little if any qualifications and who has been living in relative poverty and seeks a better life and the possibility of supporting their family who remain at in their home country.

Migrants from the rest of Africa in South Africa can be found in all categories, with significant numbers falling into the category of survival migrants. Many Zimbabwean migrants can be categorised as survival migrants. In this case, the government has at times gone beyond its obligations to international law to make provisions for them. Other migrants may be understood as coming from the bottom end of the category economic migrants.

\section{Xenophobia}

The word 'xenophobia' literally means 'the fear of foreigners or strangers' and is sometimes defined as an irrational fear of foreigners. It may be better defined as hostility towards or exclusion of foreigners or strangers. It is related to but is distinct from racism in that it uses "putative marks of "foreignness," cultural incompatibility or religion as a basis for exclusion' (Adam \& Moodley 2015:21). The roots and manifestations of xenophobia vary with contexts.

Xenophobia is often linked with acts of open violence and hostility; however, it is a more complex and pervasive phenomenon. For the sake of analysis, I will identify five major dimensions of xenophobia that may be distinguished from each other but which are interrelated with each other and reinforce each other. The first dimension is what might be described as personal xenophobia - this is the personal fear of - hostility towards and rejection of foreigners. It is often related to stereotyping of foreigners as socially undesirable. Surveys show that the majority of South Africans from all social classes and racial groups express some form of personal xenophobia (see Crush 2008). The second dimension is communal xenophobia, that is, when communities define themselves in contrast to and in exclusion from foreigners. This can be manifested in mob violence. The third dimension is institutional xenophobia - this dimension is the permeation of institutions, particularly government institutions including the police and the Department of Home Affairs, by a culture of hostility towards and rejection of foreigners. This is not expressed in regulations but in common attitudes, values and approaches adopted by the officials of the institution which reinforce a common attitude of suspicion of and hostility towards foreigners. The fourth dimension is structural xenophobia - this is when xenophobic concepts are given structural and legal form. This is more complex to describe as all states have an obligation to provide for the well-being of their own citizens and it is generally accepted that this entails that citizens are treated differently from non-citizens. It is not always easy to draw a clear line between the legitimate concern for the rights of citizens with the illegitimate hostility towards and exclusion of foreigners. An example of this is seen in the various visa and migration policies adopted by different countries which allow easier entrance to those who are regarded as desirable while excluding others or various attempts in European countries to legally restrict the outward expression of Islamic faith. It must also be emphasised that structural xenophobia can include structures and laws that were not established with the explicit intent of excluding those who are different but has the practical effect of doing this. Hence, laws within the European Union designed to promote the free movement of citizens of EU countries have the effect of excluding those from non-EU countries, particularly those from the Global South. Finally, there is what might best be described as a social ethos of xenophobia. The interaction of the four factors described above results in a pervasive ethos of xenophobia, which in turn shapes individual and communal attitudes, gives rise to institutional xenophobia and legitimates and promotes structural xenophobia.

The development of a response to xenophobia must be rooted in an adequate analysis of causal factors. Again these are multifaceted and vary from context to context. For the purposes of this article, I will briefly identify some causal factors which are relevant to the South African context.

The strong assertion of national identity. In contrast to and in part in reaction to globalisation which has emphasised international independence, there has been a widespread reassertion of national consciousness. The emphasis on free trade and the free movement of capital has coincided with restrictions on the movement of people. In the South African context, the assertion of national identity is also bound up with the history of apartheid which excluded black South Africans not only from the benefits of citizenship but also from legal citizenship through the creation of 'homelands'; legally they became foreigners in their own country. An important part of the post-apartheid era has been the assertion of a common South African national identity (Klaaren 2011; Neocosmos 2010:61-104). One consequence of this has been the defining of exclusive boundaries.

Economic inequality and deprivation. Violent xenophobia often emerges in communities where citizens of the host country are economically deprived with high rates of unemployment and where the migrants are perceived to making significant economic progress at the expense of nationals. The South African context of high levels of economic inequality, the entrapment of many in poverty and the sudden enrichment of the new elite has resulted in growing frustration on the part of the economically deprived (Gelb 2008). This is exacerbated by high levels of crime. As such, it is an ideal breeding ground for xenophobia which obscures the structural causes of poverty and enrichment.

The exploitation of migrants within the economy. Migrants whose legal status is dubious and whose recourse to the law is 
problematic, even when they have legal status, are often the victims of economic exploitation. Employers in some sectors prefer to employ migrants as they can exploit their situation by paying low wages and avoiding other legal obligations of employers (Crush \& Tshitereke 2001). This is combined with the phenomenon that as a consequence of their precarious situation, migrants often work harder and longer than nationals and are prepared to do jobs that are below their qualifications. This contributes to resentment experienced by unemployed or underemployed nationals. Both migrants and nationals are victims - one group by exploitation and the other by exclusion.

The manipulation of xenophobic attitudes by the elite. Although most political parties in South Africa have refrained from overt xenophobic manipulation, parts of the elite have encouraged it by promoting the image of migrants as criminals who prey on South Africans, thus diverting attention away from political failure to deal with crime. There is also evidence of manipulation of xenophobia at the level of local politics (Nieftagodien 2011).

The self-image of impoverished and disempowered nationals. Although hostility to foreigners can be found in all classes and racial groups in South Africa, the tendency to violent xenophobia is concentrated amongst poor and disempowered nationals. Adam and Moodley argue that this is a psychosocial consequence of being citizens in legal status, but not experiencing the social and cultural benefits of citizenship contributes to the violent expressions of xenophobia (2015:197-205).

\section{New Testament perspectives - The church as a migrant community}

The often shocking manifestations of xenophobia challenge the churches to deep self-examination as to their own participation in the emergence of a xenophobic culture, to practical engagement to counter xenophobia and to develop theological resources to respond to xenophobia. A significant aspect of a theological response to xenophobia is a re-imagination of the identity of the church in the context of mass migration. Such a re-imagination can provide theological grounds for a deep selfexamination and the theological roots for a concrete antixenophobic praxis. The starting point of the re-imagination of the identity of the church is an examination of New Testament images of the church. One image, although rarely used in the New Testament, that became popular in the early church was the image of paroikia. This is the Greek word from which we get the English word 'parish'; paroikia, however, refers to being away from home of living in a foreign place (Elliot 1981:21-48).

\section{Peter - Foreigners and immigrants ${ }^{5}$}

1 Peter addresses its readers with images drawn from Israel's experience of exile and diaspora, describing them as paripidemous (foreigners) - people who did not have citizenship in the place where they lived, who were culturally different and who were generally treated with suspicion. ${ }^{6}$ It usually referred to those who were in the locality for a short period of time. This description is qualified in two ways: firstly, these 'foreigners' were dispersed through various towns in Asia Minor. They were not only foreigners but also scattered amongst the citizens of these towns. Secondly, they were not just any foreigners, they were foreigners chosen by God, thus giving them a unique dignity and mission. Although they were despised by the society, they were honoured by God. Later in the letter, a second word is used to describe them as paroikious, that is, immigrants - people who had settled in a foreign country for a longer period of time. ${ }^{7}$ They too did not enjoy the full rights as citizens and were often discriminated against, treated with suspicion and subjected to political manipulation.

New Testament scholars disagree as to whether these people were literally migrants and foreigners (and if so, what kind of migrants they were) or whether this is a metaphorical use of the terms. Although we do not have enough information to determine this, it makes sense to read it as having a dual reference. That is, firstly, the recipients of the letters were literal foreigners and migrants - possibly people expelled from Rome (Jobes 2005:28-41) - and secondly, 1 Peter makes use of their experience as foreigners as a metaphor to describe their Christian identity and vocation. The negative experiences of being a foreigner and migrant - of not being at home, of being alienated from one's context, of being vulnerable and subject to rejection, persecution and exploitation - are thereby turned into the defining characteristics of Christian identity. Social non-identity becomes Christian identity: 'The Christians are strangers in this society - and this is precisely their vocation; that is, what they are supposed to be' (Feldmeier 1996:256). This alienation from the surrounding society is a consequence of their belonging to a community that has responded to God and so their negative experience of alienation is to be affirmed as positive for they are the community that is embodying God's eschatological future for humanity. In affirming their alienation in praxis as well as in idea, they are freed from entrapment in the values and behaviour patterns of the society in which they live in order to serve it as those who, in Christ, represent its future.

\section{Philippians - 'Our Citizenship is in Heaven'}

Paul's Letter to the Philippians in its context is a fascinating critique of Roman imperial ideology. Philippi was established as a Roman city, following the assassination of Julius Caesar by Octavian, who later became the emperor Augustus. After the victory of the army that he and Mark Antony commanded over the army of Cassius and Brutus, the town was settled with veterans from their army. He established it as Roman colony and granted its inhabitants Roman citizenship, and it was given the right to be governed as if it was a city in Italy.

6.1 Peter 1:1, see Jobes (2005:61-62), Elliot (2000:312-313) and Witherington (2007b:65-66).

7.1 Peter 2:11, see Jobes (2005:167-169), Elliot (2000:457-462, 476-483) and Witherington (2007b:137). 
Later, when Octavian's army had defeated Mark Anthony's, he settled Mark Anthony's veterans in Philippi. While at the time of Paul not all the inhabitants would have been Roman citizens, significant numbers were and many of those who were not would have aspired to it (Reumann 2008:3-4).

Paul, writing from prison, describes Christ by using the typical titles of Roman imperial ideology as 'Lord' and 'Saviour'. Unlike Octavian, however, Christ did not become 'Lord' by military victory but rather by humility, slave-like service, suffering and death - more ashamedly the death on the cross, the death reserved for the dregs of society and the non-Roman opponents of the Emperor. Crucifixion was the most degrading, shameful and disgusting way to die - it ensured continuing dishonour beyond death. ${ }^{8}$

It is in this context that Paul describes the church by using two loaded political terms. In 1:27, he uses the word politeuesthe - which means to live out one's citizenship. The Philippian Christians were to live out their citizenship in a manner worthy of the gospel. In other words, the lifestyle of the Philippian Christians in society was to be shaped by their ultimate loyalty to the crucified Lord (Fee 1995:161-163; Reumann 2008:262-264; Witherington 2011:99-102). Paul later states that the Philippians' 'citizenship' is in heaven (Phlp 3:20); he uses the Greek term politeuma, which can mean citizenship but, it more likely means something like ruling authority, government or ruling principles (Fee 1995:377-381; Witherington 2011:216-219). Whereas the city of Philippi was governed by the pattern of Rome, the church is the community governed by the pattern of heaven revealed in the crucified 'Saviour' (another imperial title) whose appearance was eagerly awaited. The logic of this terminology suggests that the gospel does not call for withdrawal from society but for a new engagement in society determined by loyalty to the crucified Christ (Compare Phlp 2:1-13). In doing this, the church becomes a critical, uncomfortable and nonconforming presence within the Empire, subverting its dominant values.

\section{Hebrews - The migrating people of God $^{9}$}

In the Letter to the Hebrews, Christians are portrayed as a community of pilgrims who are followers of Jesus who, as their leader, went ahead of them (see for example Hebrews 4:1-12 \& 12:1-12). He entered fully into the experience of human life, temptation and struggle as he journeyed towards the heavenly city through the rejection, shame, suffering and death of the cross. Christians are foreigners and strangers in the societies in which they live as they follow Jesus, migrating towards their eschatological homeland. Taking hold of their eschatological hope through faith, they are encouraged by the example of the faithful from the past and are built up through worship. They are rejected by those around them but they refuse powerful, privileged and influential positions which would compromise their dedication to the

8.See Wright (2013:279-347) for a detailed analysis of the imperial contexts of Paul's writings.

9.For a detailed discussion of the background to Hebrews and exegesis of relevant texts, see Witherington (2007a). eschatological homeland (see Hebrews 11:1-39). The way to the future leads them outside the present city, for Christ was led out of the city to be crucified and the church shares in the rejection he experienced as it migrates towards its heavenly home (see Hebrews 13-17). Yet, neither this hope of a heavenly home, nor the public rejection that it leads to, nor the social degradation that is embraced leads to otherworldliness; instead, it motivates believers to engage with society through diverse concrete acts of faith working through love (see Hebrews 11:32-40).

\section{Ephesians - Fellow citizens}

In contrast to the examples above, Ephesians presents us with a picture of Gentile Christians as: 'No longer strangers and aliens', they have become 'fellow citizens with the saints and also members of the household of God' (Eph 2:19). Here the contrast that is being drawn is not between the church and the broader society but between gentiles and Jews. Through the death of Christ, the barriers between Jews and gentiles have been broken down, reconciling both groups into one body. Believers in Christ are together members of new people that transcends the religiously enshrined divisions of the past (Eph 2:13-16) (Lincoln 1990:124-165, 257-263; Witherington 2007c). In Colossians, this emphasis on the new identity in Christ is expanded by affirming that: 'there is no longer Greek and Jew, circumcised and uncircumcised, barbarian, Scythian, slave and free' (Col 3:11). In other words, through Christ a new community is created which not only overcomes the social and religious barriers of the past but creates a new person whose unity with each other has priority over social, national and cultural divisions.

\section{Preliminary conclusions}

In different ways, these New Testament books describe the church as a foreign, problematic and disturbing community within the broader society. In contemporary South African terms, the church can therefore be called God's Makwerekwere. This foreignness has a number of significant features.

Central to the identity of the church is the confession that this One who was rejected by the religious authorities, condemned by the Roman rulers as a rebel and subjected to a death which was the symbol of degradation, humiliation and disgrace is their Lord. The cross stands opposed to all that the GrecoRoman regarded as valuable and honourable.

Loyalty to its crucified Lord transcended all other loyalties and could thus on occasion lead to conflict with secular authorities.

The values that the church embodied as a consequence of its confession of faith in Christ were at odds with the values of the societies in which the church lived, often leading to conflicts, alienation and in some cases persecution.

The church considered itself to be the people of the crucified Christ whose memberships was made up of people from diverse nations, ethnic groupings and cultural backgrounds. 
The church was God's chosen community of foreigners - it belonged to God and therefore had a transcendent dignity and honour.

These themes were developed further after the New Testament, as the conflict between the church and the society increased and organised persecution broke out.

\section{The church as God's Makwerekwere}

The image of the church as a community of foreigners, although it is not as prominent in the New Testament as other images of the church, is deeply rooted in key elements of New Testament faith so that it can be affirmed that:

Being en route as a pilgrim, realizing the resident yet alien status of Christians and Christian communities, lies at the heart of faith from the very inception of the church. Becoming a pilgrim is the calling of each individual Christian. Becoming a pilgrim community is the calling of the church. (World Council of Churches 2015:20)

Churches and denominations in South Africa are not small scattered communities with little social influence. They are large institutions with significant presence in society. The New Testament models of the church cannot simply be repeated or applied in contemporary contexts. Rather, what is required is the critical and creative appropriation of aspects of the New Testament motifs in relation to the contemporary contexts.

The word 'church' itself has diverse referents from local congregations, denominations, through ecumenical organisations, and the theological visions of the invisible universal church (Smit 2007:61-72). Critical theological interpretation of the church attempts to describe the identity of the church within the tension between theological visions and the socio-empirical realities. Affirming that the universal church only exists as it is manifested in concrete communities and human structures, the task of theological interpretation is to assist concrete communities to become more faithful manifestations of what it means to be the people of the crucified Christ. There is no one ideal manifestation of the church; different contexts provide new opportunities for a given community to manifest particular dimensions of the identity of the church. The context of extreme inequality, migration and xenophobia challenges us to re-envision what it means to be the people of the crucified Christ. One way of doing this in the light of the New Testament is to develop a model of the church as despised foreigners - as God's Makwerekwere. In this final section, I will briefly describe the contours of this model.

Firstly, imagining the church as God's Makwerekwere is a deliberate re-appropriation of a denigratory and exclusionary descriptor by institutions rooted in the dominant sociocultural matrix, with the intention of subverting the ethos of exclusion. ${ }^{10}$ Theologically, it is rooted in the confession that

10.The deliberate use of the derogatory term Makwerekwere as means to subvert its use in the dominant society raises significant issues in relation to the right to use such a term. I recognise this problematic is intensified in that I have not directly experion the attended by experiences of various forms of xenophobia. I recognise that it is not as intense as experienced by many migrants from other parts of Africa in South Africa, nor of that of many other migrants in Europe. In addition, I have been the church is the body of the rejected, excluded, degraded and crucified Jesus - the one who was a homeless stranger amongst his own people. Hence, when the excluded are a significant component of the membership of a given ecclesial community then this is to be affirmed; when they are not, then the ecclesial community is called into radical fellowship and solidarity with the excluded. It is this which constitutes the church as a foreign and disruptive body within the society in which it is manifested. In any given society, there are often numerous locations of exclusion and rejection and hence those who claim to be followers of the crucified Jesus engage in a multidirectional pilgrimage to these varied locations, identifying with the rejected in their diversity. They discover on the way that the diverse exclusionary locations are intricately linked with each other. In the New Testament, the church not only drew its membership predominantly from these groups but was also an excluded minority. Although the churches in South Africa include the poor and excluded, both local and foreigners, in their membership, they are influential social institutions which include significant numbers of the dominant classes in the economic, social and political spheres. In the context of contemporary South Africa, this means that churches need to intentionally become the church of and for the excluded, both the South Africans who are excluded from the social and cultural befits of citizenship and at the same time the rejected refugees and survival migrants. In doing so, the complex relations of power and exploitation that exclude and utilise both groups are uncovered.

Secondly, to imagine the church as God's Makwerekwere is to assert that God is in a particular way the God of the rejected and excluded in all their diversity, as was stated in the Belhar Confession. ${ }^{11}$ This is not the mere move from despising a particular group to be charitable towards them. It is a radical reversal of traditional hierarchies of honour and prestige where those who are despised in a society are affirmed and honoured as being particularly privileged by God (Bonhoeffer 2007). This does not mean some kind of magical solution to their problems but that God gives them a particular dignity and calls them to be agents of transformation in the world. The church as God's Makwerekwere affirms this particular honour and becomes the context in which those who are subjected to daily humiliation have their dignity and value of affirmed. God has chosen those who are despised to be God's instruments in the world.

Thirdly, to imagine the church as God's Makwerekwere is to confess that the church is foreign and disruptive presence in the society, because it is to be a community of reconciliation that includes excluded groups who in South African society are opposed to each other. This affirmation is a retrieval of a central insight that emerged out of the theological opposition to apartheid in a new context. From the 'Message to the

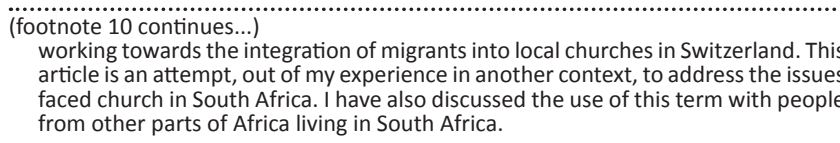
working towards the integration of migrants into local churches in Switzerland. This faced church in South Africa I expe also discussed the use of this term with people from other from other parts of Africa living in South Africa. 
people of South Africa' to the Belhar Confession churches and Christians affirmed that the body of Christ was a community of reconciliation which included people with diverse ethnic and racial identities. Division, exclusion or discrimination on the basis of ethnic or racial categorisation was incompatible with the gospel and its theological justification heresy (Villa-Vicencio \& De Gruchy 1983). In the same way, this needs to be extended to affirm that in Christ there are no Zimbabweans, Somalians, Mozambicans or South Africans. All stereotyping and political misuse of the presence of migrants is incompatible with the reconciliation in Christ. However, reconciliation in Christ is not assimilation or the removal of national and ethnic difference; it is in the particularity of our ethnic and national differences that we are reconciled to Christ and hence to each other. As communities of reconciliation, the churches are called to be inclusive communities whose life is enriched by the diversity of their members. This is not to assert that this is a simple process or an easily achievable goal. It is a call to engage in a complex and often difficult process which will encounter (considerable) hurdles along the way. However, the reality of the hardships must not be allowed to divert churches from pursuing this goal as they seek to embody the reign of God in the contemporary context.

Fourthly, to imagine the church as God's Makwerekwere is to affirm the church is a community that not merely transcends but also transgresses the boundaries of nationality and ethnicity. In the words of the Apostles creed, local and national manifestations of the church are part of the 'catholic' church, or to use a more contemporary word 'ecumenical' church, that is, the church that is present across the whole inhabited world. This affirmation is structurally present in some South African mainline churches whose membership includes churches in other Southern African countries. The members of the church are united by their common allegiance to the crucified Christ whose rule has priority over, calls into question and subverts all human authorities; hence, churches ought to always exist in critical relation to the political authorities and legal structures of particular nation states. This is not the rejection of the authority of nation states but the subjection of it to the authority of the excluded and rejected One who is present amongst the rejected and excluded of our contemporary societies.

The presence of migrants is a summons to break out of a local mindset and to discover our spiritual siblings in other countries and continents. People who because of the situations in which they migrate to new places to find work, safety and a new life, some of whom live in such situations of need that they engage in long potentially deadly journeys in search of a new life. Many of us are ignorant of the lives of these fellow members of the church - these strangers who come and those strangers who die on the way. Many of those who come to South from beyond its national boundaries are fellow Christians. ${ }^{12}$

12.A controversial case study which highlights this and the complexities that flow out of it was that of Central Methodist Church in Johannesburg, see Kuljian (2013) and Hankela (2014).

\section{Conclusion}

The presence of migrants across the world has been portrayed as a threat, has given rise to justified and unjustified fears, has been manipulated by politicians for ulterior purposes and has been responded to with various forms of structural and overt violence. However, the presence of migrants and its accompanying xenophobia provides a particular challenge to Christian churches. In this context, their presence can be perceived not as a threat but as a gift - a gift which not only challenges but also provides an opportunity to discover new ways of what it means to be the church in our contemporary world. Re-imagining the church as God's Makwerekwere is one such response. It, however, remains an academic proposal; the challenge of how to embody this in the life, liturgy and witness of churches and denominations remains.

\section{Acknowledgements Competing interests}

The author declares that he has no financial or personal relationships that may have inappropriately influenced him in writing this article.

\section{References}

Adam, H. \& Moodley, K., 2015, Imagined liberation: Xenophobia, citizenship and identity in South Africa, Germany and Canada, SUN, Stellenbosch.

Benedictus, P.P., XVI, 2005, Migration a sign of the times, viewed 14 July 2016, from http://www.zenit.org/en/articles/benedict-xvi-s-message-for-world-day-ofmigrants-and-refugees

Betts, A., 2013, Survival migration: Failed governance and the crisis of misplacement, Cornell University Press, Ithaca, NY.

Bonhoeffer, D., 2007, 'Sermon for evening worship service on 2 Corinthians 12:19 London, 1934', in K. Clements (ed.), London 1933-1935, Dietrich Bonhoeffer works, vol. 13, pp. 401-404, Fortress, Minneapolis, MN.

Cloete, G.D. \& Smit, D.J. (eds.), 1984, A moment of truth: The confession of the Dutch reformed mission church, Eerdmans, Grand Rapids, MI.

Crush, J. (ed.), 2008, The perfect storm. The realities of xenophobia in contemporary South Africa, South African Migration Project, Cape Town.

Crush, J. \& Tshitereke, C., 2001, 'Contesting migrancy: The foreign labor debate in post-apartheid South Africa', Africa Today 48(3), 115-137. https://doi. org/10.2979/AFT.2001.48.3.48

De Gruchy, J.W. \& Villa Vicencio, C. (eds.), 1983, Apartheid is a heresy, David Philip, Cape Town.

Elliot, J.H., 1981, A home for the homeless: A sociological exegesis of 1 Peter, its situation and strategy, Fortress, Philadelphia, PA.

Elliot J.H., 2000, I Peter. Anchor bible 37B, Doubleday, New York.

Fee, G.D., 1995, Paul's Letter to the Philippians, New international commentary on the New Testament, Eerdmans, Grand Rapids, MI.

Feldmeier, R., 1996, 'The "Nation" of strangers: Social contempt and its theological interpretation in ancient Judaism and early Christianity', in M.G. Brett (ed.), Ethnicity and the Bible, pp. 240-270, E.J. Brill, Leiden.

Gelb, S., 2008, 'Behind xenophobia in South Africa: Poverty or inequality?', in S. Hassim, T. Kupe \& E. Worby (eds.), Go home or die here: Violence, xenophobia and the reinvention of difference in South Africa, p. 7986, Wits University Press, the reinvention

Hankela, E., 2014, Ubuntu, migration and ministry: Being human in a Johannesburg Church, Brill, Leiden.

Hassim, S., Kupe, T. \& Worby, E. (eds.), 2008, Go home or die here: Violence, xenophobia and the reinvention of difference in South Africa, Wits University Press, Johannesburg.

Jobes, K.H., 2005, I Peter, Baker exegetical commentary, Baker, Grand Rapids, MI.

Klaaren, J., 2011, 'Citizenship, xenophobic violence and the law's dark side', in L.B. Landau (ed.), Exorcising the demons within: Xenophobia, violence and statecraft in contemporary South Africa, pp. 135-149, United Nations University Press, Tokyo.

Klotz, A., 2013, Migration, national identity in South Africa, 1860-2010, Cambridge University Press, Cambridge.

Kuljian, C., 2013, Sanctuary: How an inner-city church spilled onto a sidewalk, Jacana, Auckland Park. 
Landau, L.B. (ed.), 2011, Exorcising the demons within: Xenophobia, violence and statecraft in contemporary South Africa, United Nations University Press, Tokyo.

Lehohla, P., 2012, Census 2011: Census in brief statistics South Africa, Pretoria, viewed 14 July 2016, from http://www.statssa.gov.za/census/census_2011/census_ products/Census_2011_Census_in_brief.pd

Lincoln, A.T., 1990, Ephesians, Word Bible Commentary, vol. 42, Word, Dallas, TX.

Mwiti, L., 2015, Seven of the biggest myths about South Africa and xenophobia - And how they drive attacks in Mail and Guardian Africa, 22 April 2015, viewed 14 July 2016, from http://mgafrica.com/article/2015-04-22-six-huge-myths-about-southafricas-xenophobia

Neocosmos, M., 2010, From foreign natives to native foreigners: Explaining xenophobia in post-apartheid South Africa. Citizenship and nationalism, identity and politics, CODESRIA, Dakar.

Nieftagodien, N., 2011, 'Xenophobia's local genesis: Historical constructions of insiders and the politics of exclusion in Alexandria township', in L.B. Landau (ed.) Exorcising the demons within: Xenophobia, violence and statecraft in contemporary South Africa, pp. 135-149, United Nations University Press, Tokyo.

Nyamnjoh, F.B., 2006, Insiders and outsiders: Citizenship and xenophobia in contemporary Southern Africa, Zed, London.

OAU, 1969, Convention governing the specific aspects of refugee problems in Africa OAU, Addis Ababa, viewed 14 July 2016, from http://www.unhcr.org/about-us/ background/45dc1a682/oau-convention-governing-specific-aspects-refugeeproblems-africa-adopted.html

Oxfam, 2016, A poor welcome from the worlds wealthy: Oxfam media briefing 18 July 2016, Oxfam International, Oxford viewed 21 July 2016, from https://www. oxfam.org/sites/www.oxfam.org/files/a_poor_welcome - embargoed180716. pdf

Reumann, J., 2008, Phillipians, Anchor bible 37B, Doubleday, New York.
Smit, D., 2007, Essays in public theology: Collected essays 1, SUN, Stellenbosch.

Snyder, S., Ralston J. \& Brazal A.M. (eds.), 2016, Church in an age of global migration: A moving body, Palgrave MacMillan, Basingstoke.

United Nations, 2016, International migration report 2015: (Highlights), United Nations, New York, viewed 14 July 2016, from http://www.un.org/en/ development/desa/population/migration/publications/migrationreport/docs/ MigrationReport2015_Highlights.pdf

UNHCR, 2010, Convention and protocol relating to the status of refugees, UNHCR Geneva, viewed 14 July 2016, from http://www.unhcr.org/protection/ basic/3b66c2aa10/convention-protocol-relating-status-refugees.html

UNHCR, 2016, Global trends: Forced displacement: 2015, UNHCR, Geneva, viewed 14 July 2016, from https://s3.amazonaws.com/unhcrsharedmedia/2016/2016-0620-global-trends/2016-06-14-Global-Trends-2015.pdf

Wilkinson, K., 2015, Do five million immigrants live in SA, Mail and Guardian, 06 May 2015, viewed 14 July 2016, from http://mg.co.za/article/2015-05-06-do-5million-immigrants-live-in-sa

Witherington, B., 2007a, Letters and homilies for Jewish Christians: A socio-rhetorical commentary on Hebrews, James and Jude, InterVasity, Downers Grove, IL.

Witherington, B., 2007b, Letters and homilies for Hellenized Christians, vol. 2, A sociorhetorical commentary on 1-2 Peter, InterVasity, Downers Grove, IL.

Witherington, B., 2007c, The letters to the Philemon, the Colossians and the Ephesians: $A$ socio-rhetorical commentary on the captivity epistles, Eerdmans, Grand Rapids, MI.

Witherington, B., 2011, Paul's letter to the Philippians: A socio-rhetorical commentary, Eerdmans, Grand Rapids, MI.

World Council of Churches, 2015, The 'Other' as my neighbour: Developing an ecumenical response to migration, World Council of Churches, Geneva.

Wright, N.T., 2013, Paul and the faithfulness of God, Book 1, Fortress, Minneapolis, MN. 